\title{
Situs inversus totalis discovered incidentally at the age of 84 years
}

\author{
Vijay Bhaskar Lakshman, Swaroop Revannasiddaiah, Ravindra Ganganna
}

Department of Radiation Oncology, HealthCare Global-Bangalore Institute of Oncology, Bengaluru, Karnataka, India

\section{Correspondence to} Dr Swaroop Revannasiddaiah, swarooptheone@gmail.com
To cite: Lakshman VB, Revannasiddaiah $\mathrm{S}$, Ganganna R. BMJ Case Rep Published online: [please include Day Month Year] doi:10.1136/bcr-2013008611

\section{DESCRIPTION}

Situs inversus totalis is a rare occurrence wherein the organs of an individual are 'mirrored' in position, with the right-sided organs swapping positions with the left. The thorax features the heart placed in the right hemithorax, with the left lung being trilobed and the right lung bilobed (figure 1). The liver lies in the left, while the spleen lies in the right (figure 2).

Patients with situs inversus totalis have a $3-5 \%$ risk of congenital cardiac disease, most often the transposition of great vessels. About 20\% of patients also suffer from the Kartagener syndrome, which features bronchiectasis and sinusitis as consequences of congenital ciliary dysfunction. ${ }^{1}{ }^{2}$
However, most patients with situs inversus totalis lead normal healthy lives, and the detection of the condition is often incidental. As an example, this case describes a lady diagnosed to have situs inversus totalis at the age of 84 years, incidentally, when she was imaged as part of the evaluation for a carcinoma of the urinary bladder.

Despite the individuals leading normal routine lives, a few implications of this anatomical anomaly do exist. For example, classical clinical signs of various diseases may have to be expected on the contralateral side. Surgical interventions for any requirement must be planned keeping the patient's anatomical uniqueness in due consideration.
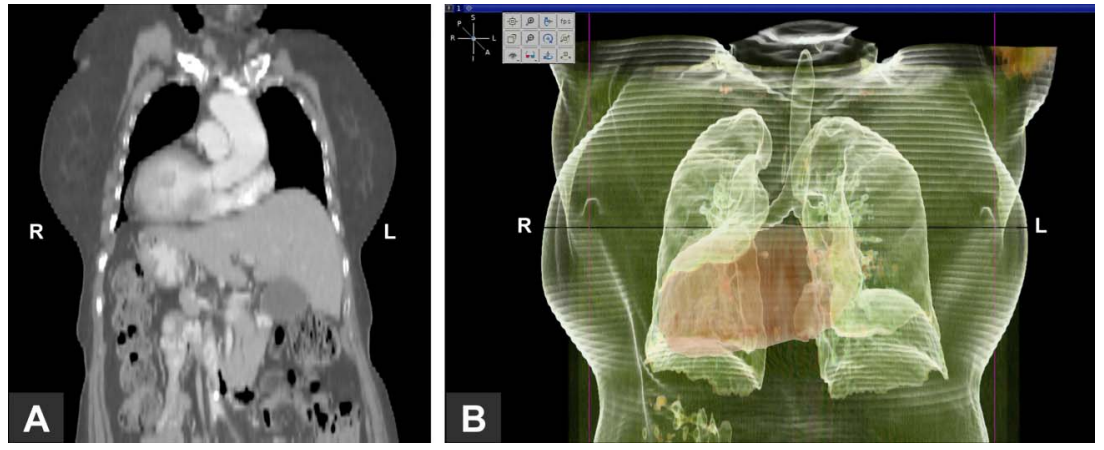

Figure 1 Coronal CT-slice (A) demonstrating the mirrored locations of the thoracoabdominal viscera. Volumetric-3 dimensional reconstruction (B) from the CT-data demonstrating the location of the cardia, and that the right lung is smaller than the left.

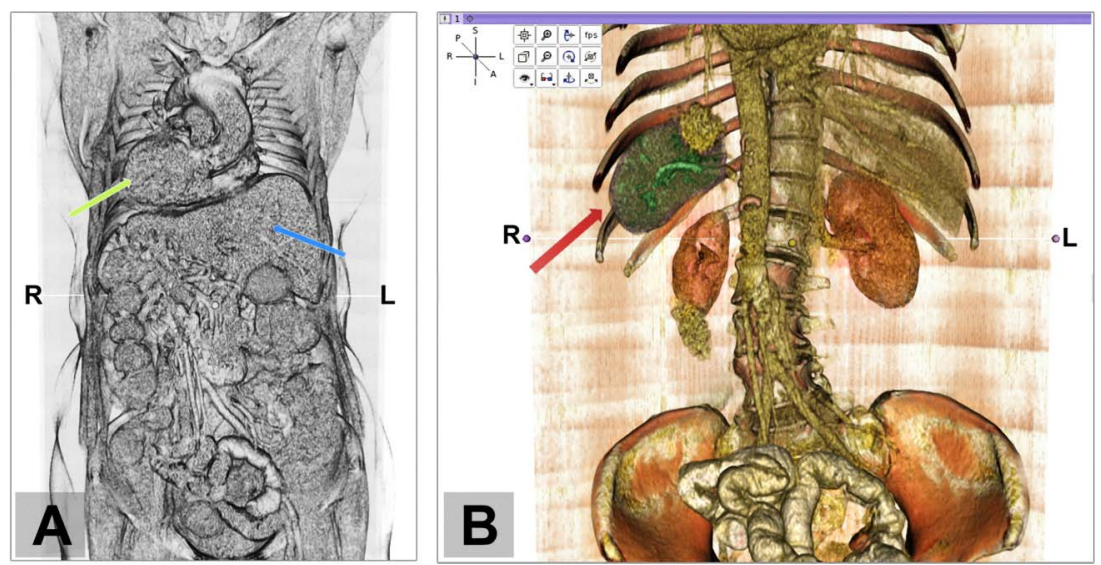

Figure 2 (A) Coronal rendition created from the CT-volumetric data depicting the mirrored positions of the heart (green arrow) and the liver (blue arrow). (B) The spleen (red arrow) visualised as located in the right side, rather than the left. 


\section{Learning points}

- Even though a majority of people situs inversus totalis lead normal healthy lives, about 1 in 20 patients may suffer cardiac anomalies and about 1 in 5 patients may have a coexisting Kartagener syndrome.

- Recognition of the condition may help prevent unanticipated difficulties and mistakes during interventional procedures.
Competing interests None.

Patient consent Obtained.

Provenance and peer review Not commissioned; externally peer reviewed.

\section{REFERENCES}

1 Hagler DJ, O'Leary PW. Cardiac malpositions and abnormalities of atrial and visceral situs. In: Emmanouilides GC, Riemenschneider TA, Allen HD, Gutgesell HP. Moss and Adams' heart disease in infants, children, and adolescents: including the fetus and young adult. Vol 2. 5th edn. Baltimore, Maryland: Williams \& Wilkins, 1995:1307-36.

2 Winer-Muram HT. Adult presentation of heterotaxic syndromes and related complexes. J Thorac Imaging 1995;10:43-57.

Copyright 2013 BMJ Publishing Group. All rights reserved. For permission to reuse any of this content visit

http://group.bmj.com/group/rights-licensing/permissions.

BMJ Case Report Fellows may re-use this article for personal use and teaching without any further permission.

Become a Fellow of BMJ Case Reports today and you can:

- Submit as many cases as you like

- Enjoy fast sympathetic peer review and rapid publication of accepted articles

- Access all the published articles

- Re-use any of the published material for personal use and teaching without further permission

For information on Institutional Fellowships contact consortiasales@bmjgroup.com

Visit casereports.bmj.com for more articles like this and to become a Fellow 